\title{
Phase Development in Carbothermal Reduction of Ilmenite Concentrates and Synthetic Rutile
}

\author{
Mohammad A. R. DEWAN, ${ }^{1)}$ Guangqing ZHANG $^{2)}$ and Oleg OSTROVSK ${ }^{21}$ \\ 1) Formerly School of Materials Science and Engineering, the University of New South Wales, now at Postdoctoral Fellow, \\ Faculty of Engineering and Industrial Sciences, Swinburne University of Technology, Hawthorn VIC 3122 Australia. \\ 2) School of Materials Science and Engineering, the University of New South Wales, UNSW SYDNEY, NSW 2052 Australia.
}

(Received on November 4, 2009; accepted on February 8, 2010)

\begin{abstract}
The phase development in the course of carbothermal reduction of ilmentie concentrates and synthetic rutile was studied in temperature programmed reduction $\left(350-1600^{\circ} \mathrm{C}\right)$ and isothermal reduction at $1100^{\circ} \mathrm{C}$ in hydrogen and $1300^{\circ} \mathrm{C}$ in argon and helium. Ilmenites and synthetic rutile were reduced in a tube reactor with continuously flowing gas. The rate and extent of reduction were monitored by online off-gas analysis. Samples reduced to different extent were subjected to XRD and SEM/BSE analyses. Pseudorutile and ilmenite were the main phases in ilmenite concentrates; rutile was the main phase in synthetic rutile. The phase changes in the course of reduction followed the same sequence in both hydrogen and inert gases. Pseudorutile was converted to ilmenite and titania; iron oxides in ilmenite were quickly reduced to metallic iron. Titania was reduced to titanium suboxides and further to titanium oxycarbide. Reduction of ilmenites and synthetic rutile in hydrogen was much faster than in inert atmosphere. The rate of conversion of titanium oxides to oxycarbide was affected by iron content in the ilmenites. The reduction of lower grade ilmenite with high iron content was faster in hydrogen; but slower in an inert gas. The latter was attributed to the higher porosity of highly weathered ilmenite and synthetic rutile.
\end{abstract}

KEY WORDS: titanium oxycarbide; ilmenite; carbothermal reduction; hydrogen; argon; helium.

\section{Introduction}

Ilmenite ore, a major raw material for titania pigment and titanium metal production, has a complex mineralogy, which has a significant effect on the ore processing. Chemistry and mineralogy of the ore are important in selecting a suitable separation process that produced a high grade concentrate. Conventional processing of the ilmenite concentrate in the Becher process includes reduction of iron oxides by coal and separation of metallic iron with production of synthetic rutile. Titania in the synthetic rutile is converted to titanium tetrachloride which is processed further to titania pigment or titanium metal. ${ }^{1)}$

Under strong reducing conditions at $1200-1300^{\circ} \mathrm{C}$, titanium oxides in the ilmenite concentrate are reduced to titanium oxycarbide. ${ }^{2)}$ Titanium oxycarbide is chlorinated at much lower temperature than titania); complete reduction of iron and manganese oxides will facilitate their removal, what is important in processing of ilmenites with high $\mathrm{Mn}$ content, such as Eucla Basin ilmenite concentrate. ${ }^{4)}$

Carbothermal reduction of ilmenites was examined in..$^{5-9)}$ Authors of this paper studied reduction of pure titania (rutile), ilmenites of different grade and synthetic rutile in different gas atmosphere. ${ }^{2,10,11)}$ In their studies, titanium oxides were reduced to titanium oxycarbide, while iron and manganese oxides were reduced to the metallic state. It was shown that carbothermal reduction of ilmenite concentrates strongly depends on temperature, gas composition and con- centrate grade. Synthesis of titanium oxycarbide was much faster in hydrogen than in argon or helium. The rate of reduction of titanium oxides to oxycarbide was affected by the iron content; it was higher for ilmenite of lower grade with higher iron concentration.

This paper reports phase development in reduction of ilmenites and synthetic rutile in different gas atmospheres.

\section{Experimental}

The chemical analysis of ilmenite concentrates and synthetic rutile is presented in Table 1. XRD analysis showed

Table 1. Chemical composition of ilmenite concentrates (wt $\%)$.

\begin{tabular}{ccccc}
\hline Composition & $\begin{array}{c}\text { Primary } \\
\text { Ilmenite }\end{array}$ & $\begin{array}{c}\text { Secondary } \\
\text { Ilmenite }\end{array}$ & HYTI 70 & Synthetic Rutile \\
\hline $\mathrm{TiO}_{2}$ & 53.90 & 58.20 & 71.50 & $92.50^{\mathrm{a}}$ \\
$\mathrm{Ti}_{2} \mathrm{O}_{3}$ & & & & $12.10^{\mathrm{b}}$ \\
$\mathrm{Total} \mathrm{Fe}$ & 30.50 & 25.90 & 14.50 & 2.80 \\
$(\mathrm{Fe}+\mathrm{Mn})$ & & & & 3.47 \\
$\mathrm{FeO}$ & 18.00 & 11.20 & 1.20 & - \\
$\mathrm{Fe}_{2} \mathrm{O}_{3}$ & 23.60 & 24.50 & 19.40 & - \\
$\mathrm{MnO}_{\mathrm{n} O}$ & 1.63 & 1.15 & 0.71 & 0.86 \\
$\mathrm{SiO}_{2}$ & 0.27 & 0.75 & 0.78 & 0.91 \\
$\mathrm{ZrO}_{2}$ & 0.09 & 0.16 & 0.16 & 0.09 \\
$\mathrm{P}_{2} \mathrm{O}_{5}$ & 0.01 & 0.03 & 0.09 & 0.02 \\
$\mathrm{Al}_{2} \mathrm{O}_{3}$ & 0.40 & 0.51 & 1.70 & 0.97 \\
$\mathrm{~S}$ & 0.004 & 0.005 & 0.05 & 0.63 \\
$\mathrm{Nb}_{2} \mathrm{O}_{5}$ & 0.10 & 0.14 & 0.32 & 0.23 \\
$\mathrm{Cr}_{2} \mathrm{O}_{3}$ & 0.047 & 0.05 & 0.100 & 0.07 \\
$\mathrm{CaO}_{\mathrm{MgO}}$ & $<0.01$ & $<0.01$ & 0.04 & 0.02 \\
$\mathrm{MgO}_{2} \mathrm{O}_{5}$ & 0.18 & 0.22 & 0.10 & 0.36 \\
$\mathrm{Ti}_{5} / \mathrm{Fe}$ & 0.17 & 0.18 & 0.29 & 0.28 \\
\hline $\mathrm{a}$ & $1.24: 1$ & $1.57: 1$ & $2.49: 1$ & $26.46: 1$ \\
\hline $\mathrm{Based}$ & & &
\end{tabular}

${ }^{\mathrm{a}}$ Based on total titanium content. ${ }^{\mathrm{b}}$ Equivalent content of all titanium suboxides. 
that primary ilmenite contains mainly ilmenite $\mathrm{FeTiO}_{3}$ and pseudorutile $\mathrm{Fe}_{2} \mathrm{Ti}_{3} \mathrm{O}_{9}$ phases, while secondary and HYTI70 ilmenites also contain rutile. Titania $\left(\mathrm{TiO}_{2}\right)$ was the major phase in the synthetic rutile. Chemical analysis showed that synthetic rutile contained titanium suboxides equivalent to $12.1 \mathrm{wt} \% \mathrm{Ti}_{2} \mathrm{O}_{3}$.

As received ilmenite concentrates and synthetic graphite (99.5\% purity, $<20 \mu \mathrm{m}$ in particle size) were wet mixed and pressed into cylindrical pellets. The ilmenite-graphite mixture contained $10 \mathrm{~mol} \%$ extra graphite to the stoichiometric amount of carbon necessary to reduce oxides of titanium, iron and manganese present in the ilmenite. The contents of other oxides were low, and they were considered to be unreducible under given experimental conditions. The pellets of about $2 \mathrm{~g}$ in weight were $8 \mathrm{~mm}$ in diameter and about $12 \mathrm{~mm}$ high.

Reduction of ilmenite concentrates and synthetic rutile by graphite in hydrogen, argon and helium gases was studied in a laboratory fixed bed reactor in a vertical tube electric furnace. Experimental set-up and procedure were presented elsewhere. ${ }^{12)}$ The stages and phase development during reduction of different grade of ilmenites in various atmospheres were studied by temperature programmed reduction experiments by ramping furnace temperature from 350 to $1600^{\circ} \mathrm{C}$ at $3^{\circ} \mathrm{C} / \mathrm{min}$. The reduction was stopped at different stages and the phase composition of samples analysed by XRD. Further investigation was done by isothermal reduction, at $1100^{\circ} \mathrm{C}$ in hydrogen and at $1300^{\circ} \mathrm{C}$ in argon. The outlet gas was analysed online by an infrared $\mathrm{CO} / \mathrm{CO}_{2} / \mathrm{CH}_{4}$ analyser (Advanced Optima AO2020, ABB, Ladenburgh, Germany). The total gas flow rate was maintained at $1.00 \mathrm{NL} / \mathrm{min}$.

The reduced pellets were analysed by XRD with Philips X'Pert-Pro MPD diffractometer (PANalytical, Lelyweg, Netherlands) with $\mathrm{Cu} K \alpha$ radiation. Back Scattered Electron (BSE) images of samples ware taken by Hitachi S3400 (Hitachi, Mito Japan) using $60 \mathrm{kV}$ accelerating voltage and elemental analysis of the samples were conducted with Energy dispersive X-ray spectroscopy (EDS, Noran, Waltham, US).

\section{Results}

\subsection{Temperature Programmed Reduction}

Temperature-programmed carbothermal reduction experiments were carried out in hydrogen, argon and helium in the temperature range of $350-1600^{\circ} \mathrm{C}$ with a ramping rate of $3^{\circ} \mathrm{C} / \mathrm{min}$.

Carbothermal reduction reactions in inert atmosphere produced $\mathrm{CO}$, while in the course of reduction in hydrogen, $\mathrm{H}_{2} \mathrm{O}$ was also evolved. Rates of evolution of $\mathrm{H}_{2} \mathrm{O}$ and $\mathrm{CO}$ in reduction experiments in different gas atmospheres for secondary ilmenite, HYTI70 and synthetic rutile are presented in Fig. 1.

The reduction curves for primary, ${ }^{2)}$ secondary (Fig. 1(a)) and HYTI70 (Fig. 1(b)) ilmenites had similar shapes. Reduction in hydrogen started with conversion of pseudorutile to ilmenite and titania, followed by reduction of $\mathrm{FeO}$ from ilmenite to metallic iron and partial reduction of titania to titanium suboxides. In the process of reduction in hydrogen, $\mathrm{CO}$ started to evolve in the reduction of secondary ilmenite

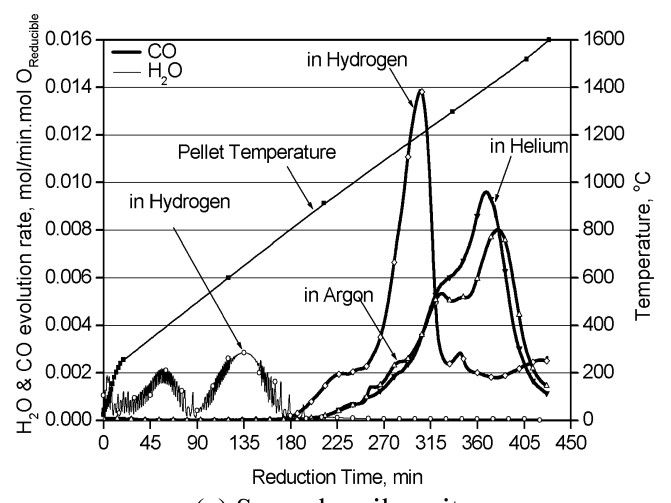

(a) Secondary ilmenite

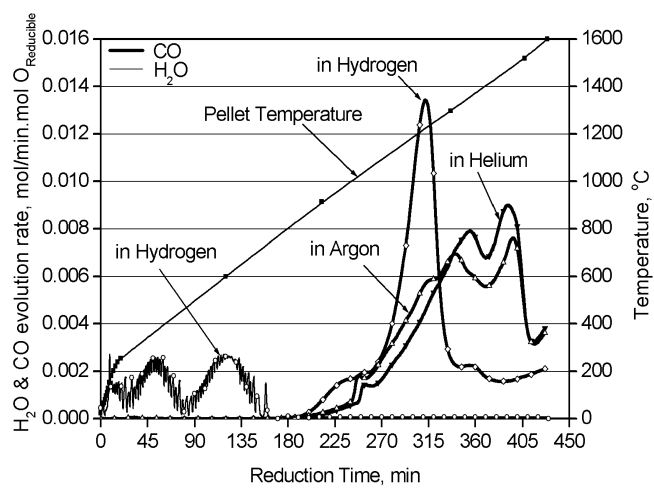

(b) HYTI70 ilmenite

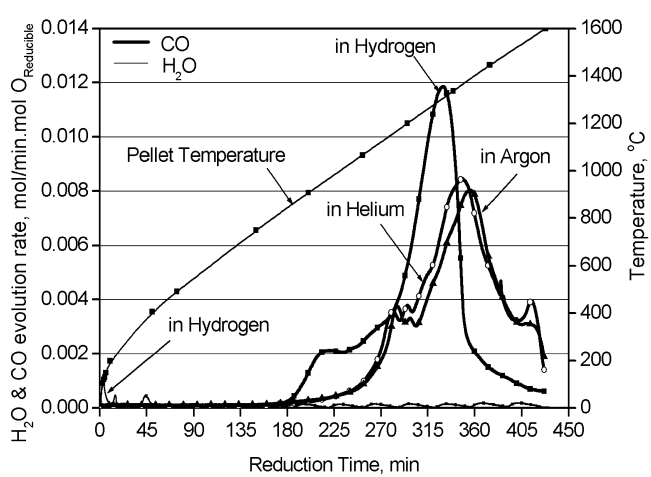

(c) Synthetic rutile

Fig. 1. $\mathrm{H}_{2} \mathrm{O}$ and $\mathrm{CO}$ evolution rates in temperature programmed reduction of ilmenite concentrates and synthetic rutile in different gas atmospheres. The furnace temperature was ramped from 350 to $1600^{\circ} \mathrm{C}$ at $3^{\circ} \mathrm{C} / \mathrm{min}$.

at $780^{\circ} \mathrm{C}$ and in the reduction of HYTI 70 at $835^{\circ} \mathrm{C}$. In both cases, the main $\mathrm{CO}$ peak corresponded to about $1200^{\circ} \mathrm{C}$.

Figure 2 presents XRD patterns of secondary ilmenite in the progress of reduction in hydrogen. The XRD analysis of the sample heated to $510^{\circ} \mathrm{C}$ when the first water evolution peak terminated detected titania and unreduced ilmenite with negligible amount of metallic iron. At this temperature, pseudorutile was completely reduced to ilmenite and titania by Reaction (1):

$$
\mathrm{Fe}_{2} \mathrm{Ti}_{3} \mathrm{O}_{9}+\mathrm{H}_{2} \rightarrow 2 \mathrm{FeTiO}_{3}+\mathrm{TiO}_{2}+\mathrm{H}_{2} \mathrm{O} .
$$

At $750^{\circ} \mathrm{C}$ ilmenite was mostly converted to titania and metallic iron:

$$
\mathrm{FeTiO}_{3}+\mathrm{H}_{2} \rightarrow \mathrm{Fe}+\mathrm{TiO}_{2}+\mathrm{H}_{2} \mathrm{O} \text {. }
$$

When the reduction was stopped at $1010^{\circ} \mathrm{C}$, titanium was mainly in the form of $\mathrm{Ti}_{3} \mathrm{O}_{5}$, although $\mathrm{Ti}_{2} \mathrm{O}_{3}$ was also detected in a small amount. Reduction of titania to $\mathrm{Ti}_{3} \mathrm{O}_{5}(\mathrm{Re}-$ 


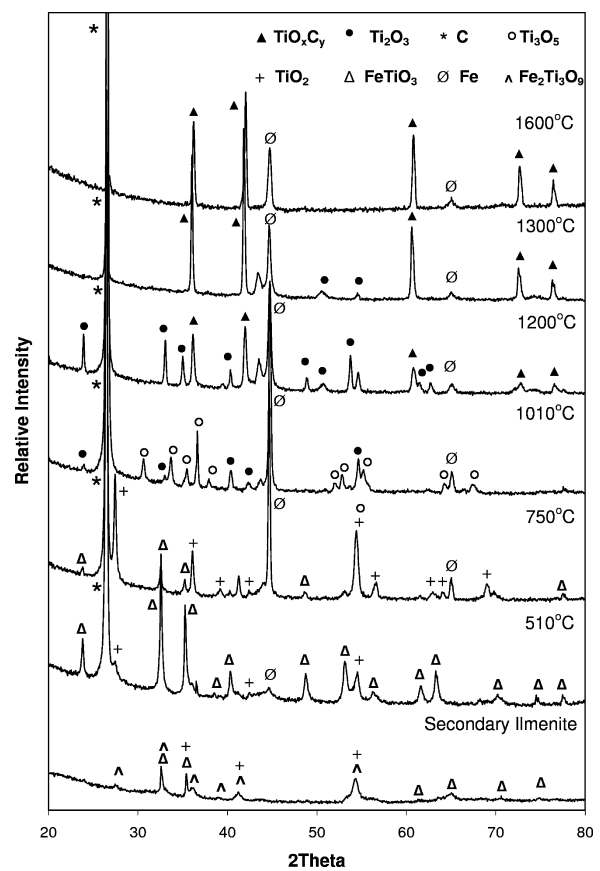

Fig. 2. XRD patterns of secondary ilmenite in the progress of temperature programmed reduction in hydrogen. Furnace temperature was ramped at $3^{\circ} \mathrm{C} / \mathrm{min}$.

action (3)) was reflected in a shoulder peak prior to the main $\mathrm{CO}$ peak.

$$
3 \mathrm{TiO}_{2}+\mathrm{C} \rightarrow \mathrm{Ti}_{3} \mathrm{O}_{5}+\mathrm{CO}
$$

With increasing temperature $\mathrm{Ti}_{3} \mathrm{O}_{5}$ was further reduced to $\mathrm{Ti}_{2} \mathrm{O}_{3}$ :

$$
2 \mathrm{Ti}_{3} \mathrm{O}_{5}+\mathrm{C} \rightarrow 3 \mathrm{Ti}_{2} \mathrm{O}_{3}+\mathrm{CO}
$$

Actually, $\mathrm{TiO}_{2}$ and $\mathrm{Ti}_{3} \mathrm{O}_{5}$ were reduced by $\mathrm{H}_{2}$. Water formed by the reduction was consumed by carbon gasification reaction. As a result, $\mathrm{CO}$ was observed as a reduction product.

The amount of $\mathrm{Ti}_{2} \mathrm{O}_{3}$ achieved the maximum at $1200^{\circ} \mathrm{C}$, which corresponded to the maximum $\mathrm{CO}$ evolution rate. The sample also contained significant amount of titanium oxycarbide, which was the major phase in the sample quenched at $1300^{\circ} \mathrm{C} . \mathrm{TiO}_{x} \mathrm{C}_{y}$ is the solid $\mathrm{TiO}-\mathrm{TiC}$ solution which was formed by the reduction Reactions (5) and (6):

$$
\begin{gathered}
\mathrm{Ti}_{2} \mathrm{O}_{3}+\mathrm{C} \rightarrow 2[\mathrm{TiO}]_{\mathrm{ss}}+\mathrm{CO} . \\
\mathrm{Ti}_{2} \mathrm{O}_{3}+5 \mathrm{C} \rightarrow 2[\mathrm{TiC}]_{\mathrm{ss}}+3 \mathrm{CO} .
\end{gathered}
$$

In Reactions (5) and (6), methane was involved as a reaction intermediate. ${ }^{2)}$

The amount of water evolved in temperature programmed reduction of synthetic rutile was negligible, as shown by the reduction curve of synthetic rutile in hydrogen (Fig. 1(c)) in which the water peaks are almost invisible. These peaks are related to reduction of iron oxides, which concentration in the synthetic rutile was very low. In the reduction of synthetic rutile, $\mathrm{CO}$ started to evolve at about the same temperature as in reduction of ilmenites of lower grade. However, the $\mathrm{CO}$ peak corresponded to a temperature by $80-100^{\circ} \mathrm{C}$ higher and it was lower and wider compared with other ilmenite concentrates.

The reduction curves in helium and argon for all il-

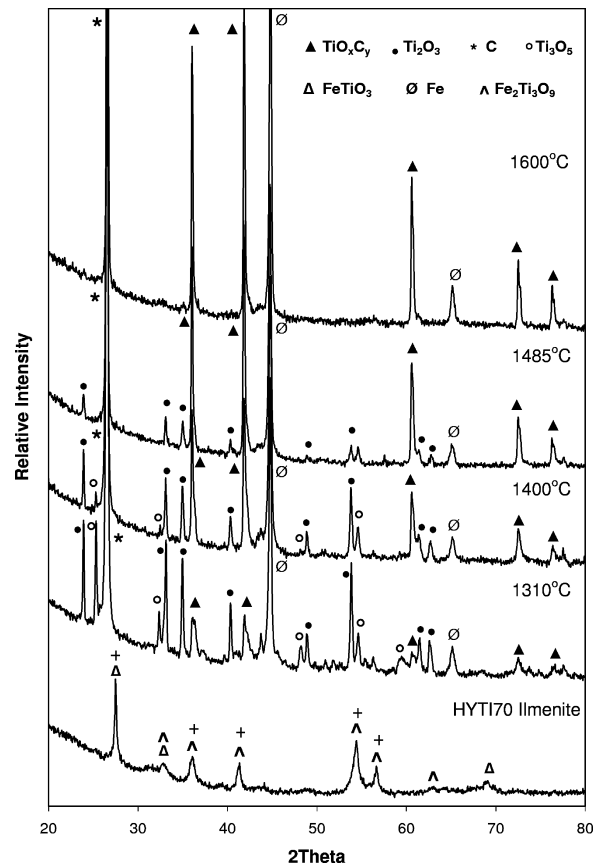

Fig. 3. XRD patterns of HYTI70 ilmenite in the progress of temperature programmed reduction in argon. Furnace temperature was ramped at $3^{\circ} \mathrm{C} / \mathrm{min}$.

menites and synthetic rutile included two overlapped $\mathrm{CO}$ peaks at higher temperature range than that in hydrogen. Reduction in helium was slightly faster than in argon.

XRD analysis of HYTI70 in the progress of reduction in argon is presented in Fig. 3. The relative intensity of the iron peak in the XRD spectra of samples heated to $1310^{\circ} \mathrm{C}$ and above practically did not change with the sample temperature, meaning that reduction of iron oxides was completed at $1310^{\circ} \mathrm{C}$. A sample, heated to $1310^{\circ} \mathrm{C}$ also contained $\mathrm{Ti}_{2} \mathrm{O}_{3}$ (the main titanium containing phase), $\mathrm{Ti}_{3} \mathrm{O}_{5}$ and $\mathrm{TiO}_{x} \mathrm{C}_{y}$. Further ramping temperature resulted in waning $\mathrm{Ti}_{3} \mathrm{O}_{5}$ and $\mathrm{Ti}_{2} \mathrm{O}_{3}$ peaks, with corresponding rising $\mathrm{TiO}_{x} \mathrm{C}_{y}$ peaks. In the quenched sample heated to $1400^{\circ} \mathrm{C}$, the main titanium-containing phases were $\mathrm{Ti}_{2} \mathrm{O}_{3}$ and $\mathrm{TiO}_{x} \mathrm{C}_{y}$, with a small amount of $\mathrm{Ti}_{3} \mathrm{O}_{5}$. The same phases but $\mathrm{Ti}_{3} \mathrm{O}_{5}$ were identified by XRD in the sample quenched at $1485^{\circ} \mathrm{C}$ (the main $\mathrm{CO}$ evolution peak); $\mathrm{TiO}_{x} \mathrm{C}_{y}$ was the major titanium-containing phase. The sample heated to $1600^{\circ} \mathrm{C}$ contained $\mathrm{TiO}_{x} \mathrm{C}_{y}$, metallic iron and unreacted carbon.

Unlike reduction in hydrogen with separated reduction stages, steps of ilmenite reduction in inert gas occurred with significant overlapping. Reduction of iron oxides proceeded simultaneously with reduction of titania to $\mathrm{Ti}_{3} \mathrm{O}_{5}$ and further to $\mathrm{Ti}_{2} \mathrm{O}_{3}$ (first $\mathrm{CO}$ peak). Titanium oxycarbide started to evolve before completion of $\mathrm{Ti}_{3} \mathrm{O}_{5}$ converting to $\mathrm{Ti}_{2} \mathrm{O}_{3}$ (the second $\mathrm{CO}$ peak). First peaks of reduction of synthetic rutile with low iron oxide content in inert gases were significantly smaller than those of ilmenite concentrates.

\subsection{Phase Development in Isothermal Reduction of Il- menite Concentrates}

The XRD patterns of samples of secondary ilmenite in the progress of reduction in hydrogen at $1100^{\circ} \mathrm{C}$ are presented in Fig. 4. Main phases in the original secondary il- 


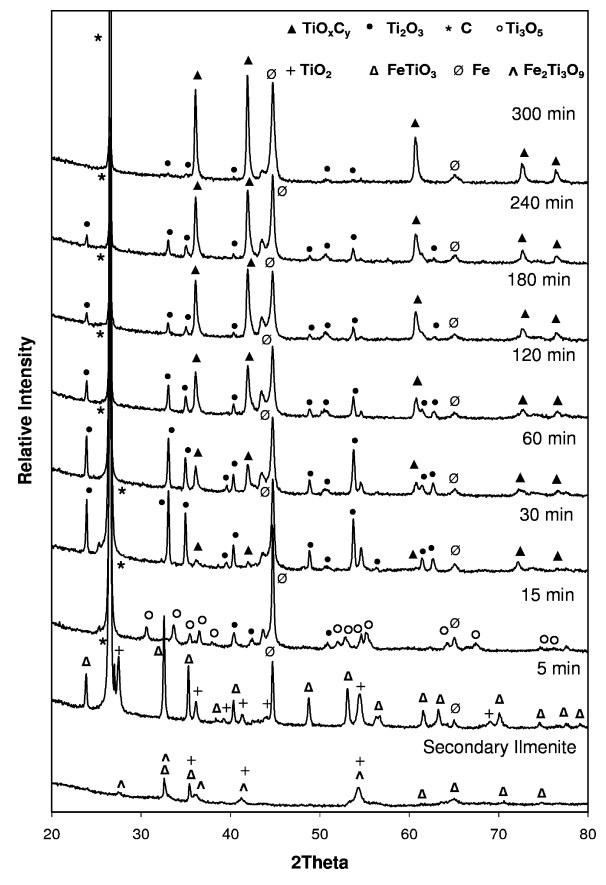

Fig. 4. XRD patterns of secondary ilmenite in progress of reduction in hydrogen at $1100^{\circ} \mathrm{C}$.

menite were pseudorutile and ilmenite. $\mathrm{Fe}_{2} \mathrm{Ti}_{3} \mathrm{O}_{9}$ was undetectable after $5 \mathrm{~min}$ reduction; the sample contained $\mathrm{TiO}_{2}$, $\mathrm{FeTiO}_{3}$ and metallic iron. In $15 \mathrm{~min}, \mathrm{TiO}_{2}$ and $\mathrm{FeTiO}_{3}$ phases disappeared; the XRD spectrum showed a significant amount of $\mathrm{Ti}_{3} \mathrm{O}_{5}, \mathrm{Ti}_{2} \mathrm{O}_{3}$ and metallic iron. It should be noted that it took about $15-20 \mathrm{~min}$ for the sample temperature to reach the experimental value since the sample was placed in the maximum heated zone in the reduction furnace, so the reaction within the first $15-20 \mathrm{~min}$ occurred at temperatures below $1100^{\circ} \mathrm{C}$. Conversion of $\mathrm{Ti}_{3} \mathrm{O}_{5}$ to $\mathrm{Ti}_{2} \mathrm{O}_{3}$ was completed after $30 \mathrm{~min} . \mathrm{TiO}_{x} \mathrm{C}_{y}$ phase was first observed after 30 min reaction, which content consistently increased with reduction time, with corresponding waning of $\mathrm{Ti}_{2} \mathrm{O}_{3}$ peaks. After 300 min reduction, the sample consisted of metallic $\mathrm{Fe}, \mathrm{TiO}_{x} \mathrm{C}_{y}$ residual carbon, and a very small amount of uncarburised $\mathrm{Ti}_{2} \mathrm{O}_{3}$.

Reduction of secondary ilmenite in hydrogen was similar to that of primary ilmenite. ${ }^{2)}$ Progress of reduction of HYTI70 in hydrogen (Fig. 5) also followed the same sequence, but with a slower development of titanium oxycarbide phase. Traces of $\mathrm{TiO}_{x} \mathrm{C}_{y}$ were observed in $30 \mathrm{~min}$; the amount of this phase slowly increased with increasing reduction time. After $120 \mathrm{~min}, \mathrm{Ti}_{2} \mathrm{O}_{3}$ still was the major titanium containing phase. The amount of $\mathrm{Ti}_{2} \mathrm{O}_{3}$ decreased to a very low level after 300 min reduction.

The phase development in the course of reduction of ilmenite concentrates in argon and helium was studied at $1300^{\circ} \mathrm{C}$. The XRD patterns of secondary ilmenite and HYTI70 reduced in argon are presented in Figs. 6 and 7, respectively. XRD spectra of samples reduced in helium were similar to those obtained in argon.

Carbothermal reduction in inert gases followed the same sequence as in hydrogen, but progressed slower although the temperature was raised to $1300^{\circ} \mathrm{C}$. Compared to secondary ilmenite, reduction of HYTI70 was slightly slower. After 5 min reduction, the main phases in both ilmenite

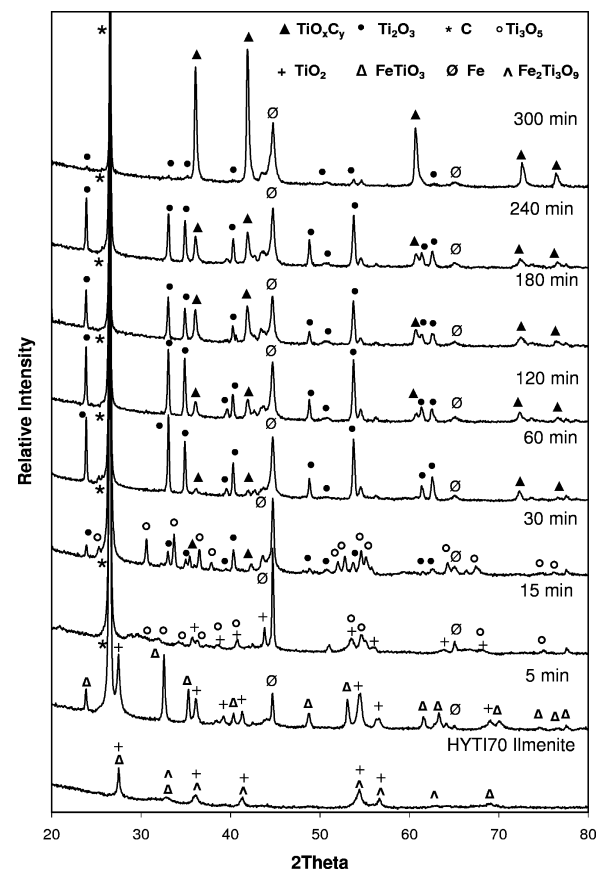

Fig. 5. XRD patterns of HYTI70 ilmenite in progress of reduction in hydrogen at $1100^{\circ} \mathrm{C}$.

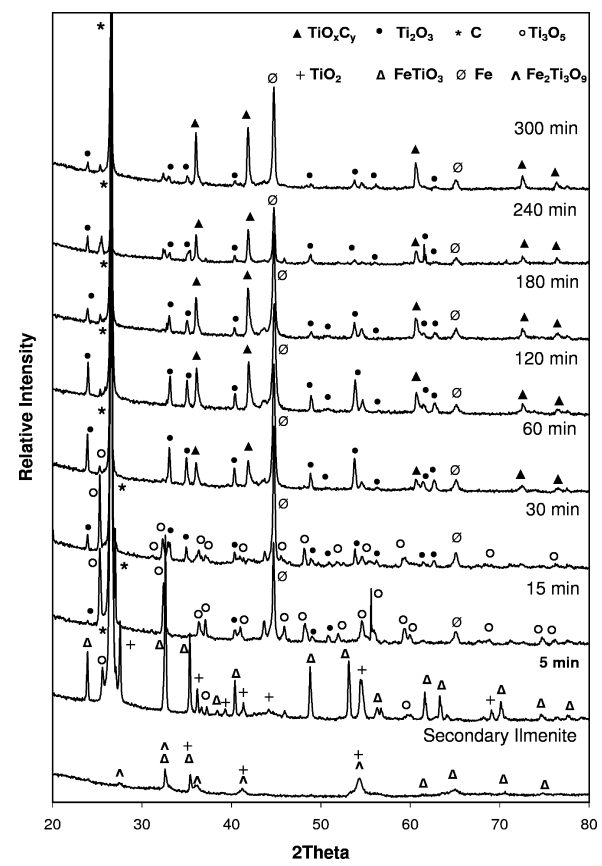

Fig. 6. XRD patterns of secondary ilmenite in progress of reduction in argon at $1300^{\circ} \mathrm{C}$.

concentrates were ilmenite and $\mathrm{TiO}_{2} ; \mathrm{Fe}_{2} \mathrm{Ti}_{3} \mathrm{O}_{9}$ and metallic iron were not observed. Trace of $\mathrm{Ti}_{3} \mathrm{O}_{5}$ was also detected in the reduced secondary ilmenite. After 15 min reduction, metallic $\mathrm{Fe}$ was detected in a significant amount. Extending reduction to $30 \mathrm{~min}$ completed reduction of ilmenite. Conversion of $\mathrm{Ti}_{3} \mathrm{O}_{5}$ to $\mathrm{Ti}_{2} \mathrm{O}_{3}$ was not completed until $60 \mathrm{~min}$ in secondary ilmenite, and lasted longer in HYTI70. Further conversion of $\mathrm{Ti}_{2} \mathrm{O}_{3}$ to titanium oxycarbide did not complete after $300 \mathrm{~min}$; the reduced samples contained metallic iron, $\mathrm{TiO}_{x} \mathrm{C}_{y}$, residual $\mathrm{Ti}_{2} \mathrm{O}_{3}$ and graphite. 


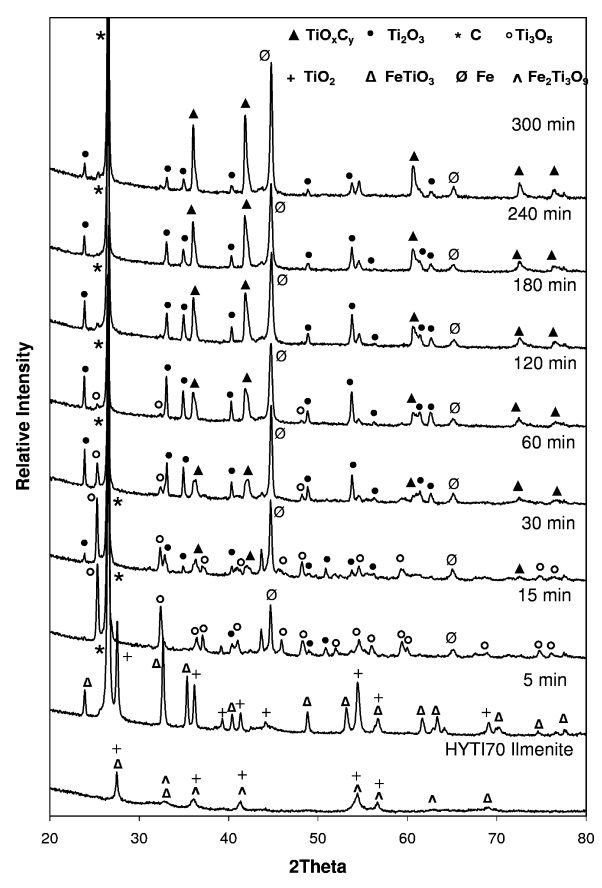

Fig. 7. XRD patterns of HYTI70 ilmenite in progress of reduction in argon at $1300^{\circ} \mathrm{C}$.

\subsection{Phase Development in Reduction of Synthetic Ru- tile}

Synthetic rutile contained very little iron $(2.8 \mathrm{wt} \%$ total $\mathrm{Fe}$ ) and high titanium content, equivalent to $92.5 \%$ of $\mathrm{TiO}_{2}$. It also contained partially reduced suboxides, mainly in the form of $\mathrm{Ti}_{3} \mathrm{O}_{5}$ as shown by XRD analysis.

The XRD spectra of synthetic rutile in progress of reduction in hydrogen at $1100^{\circ} \mathrm{C}$ and in argon at $1300^{\circ} \mathrm{C}$ are presented in Figs. 8 and 9, respectively. After reduction for $5 \mathrm{~min}$ in hydrogen (Fig. 8), iron oxides were reduced to metallic iron. Reduction of $\mathrm{TiO}_{2}$ to $\mathrm{Ti}_{3} \mathrm{O}_{5}$ was completed within the first $15 \mathrm{~min}$. In the sample reduced for $30 \mathrm{~min}$, titanium oxycarbide was observed; its amount slowly increased, although in the sample reduced for 120 min $\mathrm{Ti}_{2} \mathrm{O}_{3}$ was the main component. After $300 \mathrm{~min}$ reduction, the reduced sample contained metallic iron, $\mathrm{TiO}_{x} \mathrm{C}_{y}$, graphite and significant amount of residual $\mathrm{Ti}_{2} \mathrm{O}_{3}$. Compared to ilmenite concentrates, the reduction of synthetic rutile and formation of titanium oxycarbide in hydrogen were slower.

Reduction of synthetic rutile in argon at $1300^{\circ} \mathrm{C}$ (Fig. 9) was faster than in hydrogen at $1100^{\circ} \mathrm{C}$, which was opposite to what was observed in reduction of ilmenite concentrates. After $5 \mathrm{~min}$ of reduction, the main identified phases were $\mathrm{TiO}_{2}, \mathrm{Ti}_{3} \mathrm{O}_{5}$ and reduced iron. Significant amount of $\mathrm{Ti}_{2} \mathrm{O}_{3}$ was produced in a sample reduced for $15 \mathrm{~min}$ in argon, although it was hardly detectable in reduction in hydrogen at $1100^{\circ} \mathrm{C}$. $\mathrm{TiO}_{x} \mathrm{C}_{y}$ was observed in samples reduced in argon after 30 min reduction, while $\mathrm{Ti}_{2} \mathrm{O}_{3}$ was the main component. The residual $\mathrm{Ti}_{2} \mathrm{O}_{3}$ content in the sample reduced for 300 min was much lower than in the sample reduced in hydrogen.

\section{Discussion}

Main phases in ilmenite concentrates were ilmenite and pseudorutile. Reduction of ilmenites started with conver-

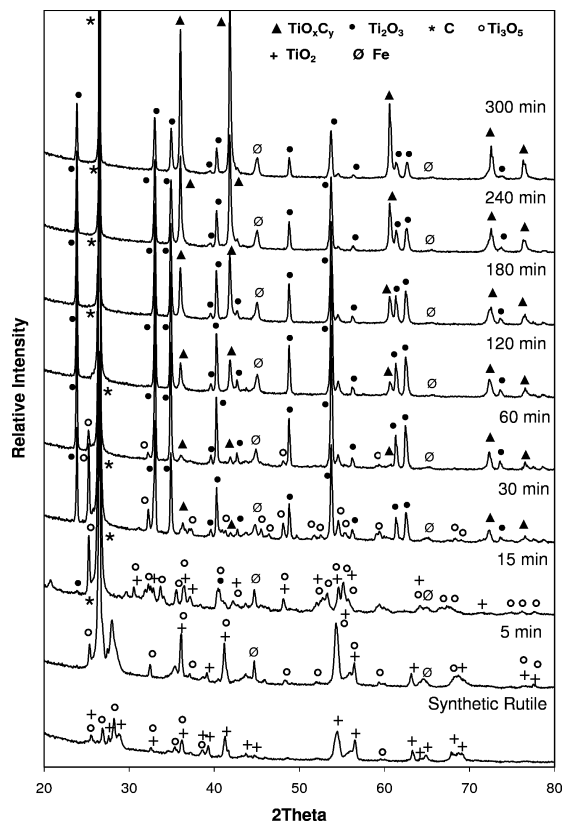

Fig. 8. XRD patterns of synthetic rutile in progress of reduction in hydrogen at $1100^{\circ} \mathrm{C}$.

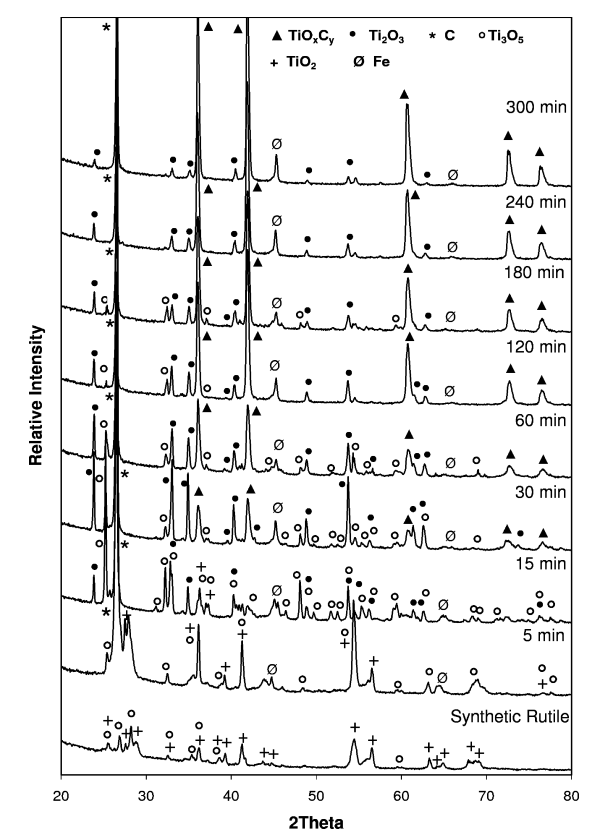

Fig. 9. XRD patterns of synthetic rutile in progress of reduction in argon at $1300^{\circ} \mathrm{C}$.

sion of pseudorutile to ilmenite and titania, followed by further reduction of ilmenite to metallic iron and titania. Titania was reduced to sub-oxides and further to titanium oxycarbide. The reduction sequence, which follows from the analysis of phase development, can be presented as:

$$
\begin{aligned}
\mathrm{Fe}_{2} \mathrm{Ti}_{3} \mathrm{O}_{9} \rightarrow \mathrm{FeTiO}_{3}+\mathrm{TiO}_{2} \rightarrow \mathrm{Fe}+\mathrm{TiO}_{2} \rightarrow \cdots \\
\quad \rightarrow \mathrm{Fe}+\mathrm{Ti}_{3} \mathrm{O}_{5} \rightarrow \mathrm{Fe}+\mathrm{Ti}_{2} \mathrm{O}_{3} \rightarrow \mathrm{Fe}+\mathrm{TiO}_{x} \mathrm{C}_{y}
\end{aligned}
$$

Carbothermal reduction of metal oxides proceeds through the gas phase. Gas atmosphere had a strong effect on the rate and extent of carbothermal reduction of ilmenite concentrate and synthetic rutile. Reduction of ilmenites of all grades in hydrogen was faster than in inert atmosphere under otherwise the same conditions. This was discussed 

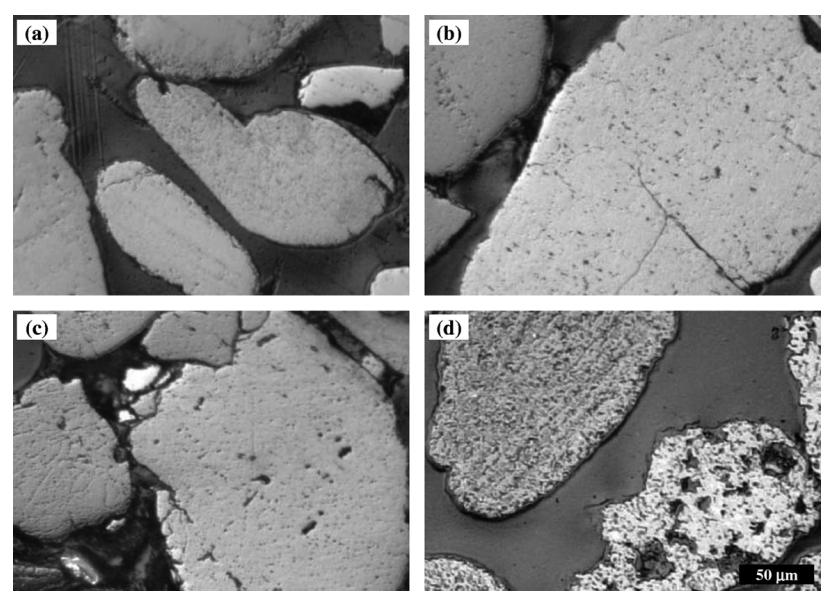

Fig. 10. Optical images of original ilmenite concentrates and synthetic rutile. (a) Primary ilmenite; (b) secondary ilmenite; (c) HYTI70; (d) synthetic rutile.

in. ${ }^{2,11)}$ In the process of carbothermal reduction in $\mathrm{H}_{2}$, hydrogen reduced iron oxides to metallic iron and titania to titanium sub-oxides, up to $\mathrm{Ti}_{2} \mathrm{O}_{3}$. Reacting with carbon, hydrogen formed methane, which reduced $\mathrm{Ti}_{2} \mathrm{O}_{3}$ to titanium oxycarbide.

Figure 10 presents optical images of original ilmenite concentrates and synthetic rutile. The degree of weathering and particle porosity increased with increasing concentrate grade and was the highest for synthetic rutile. Metallic iron was also observed in some synthetic rutile particles.

The morphology of ilmenite concentrates changed in the process of reduction; this change depended on the concentrate grade and the gas atmosphere. BSE images of primary ilmenite concentrate in progress of reduction in hydrogen at $1100^{\circ} \mathrm{C}$ and in helium at $1300^{\circ} \mathrm{C}$ are shown in Fig. 11. Reduction of iron oxides from ilmenite concentrates by hydrogen was very fast; fine iron grains were formed and a porous structure within the titanium oxide matrix was developed. Reduction of ilmenites in inert gases resulted in formation of coarse grains of metallic iron with a denser particle structure in comparison with reduction in hydrogen. Originally most dense structure of primary ilmenite with the highest concentration of iron oxides, after reduction of iron oxides by hydrogen converted to the least dense structure. This positively affected the rate of conversion of titania to oxycarbide. Reduction of synthetic rutile with a small amount of iron oxides was not affected. The higher was a content of iron oxide in the ilmenite concentrate, the higher was the rate of reduction in hydrogen.

Reduction of iron oxides from ilmenites in argon or helium was relatively slow and proceeded at higher temperatures, producing coarse iron grains. In this case, the change in the particle structure was not significant; the original particle porosity was the major factor defining the conversion of ilmenite to iron and titanium oxycarbide. This conversion was the fastest in the case of synthetic rutile which had the highest porosity.

\section{Conclusions}

Development of different phases was examined in progress of carbothermal reduction of ilmenite concentrates

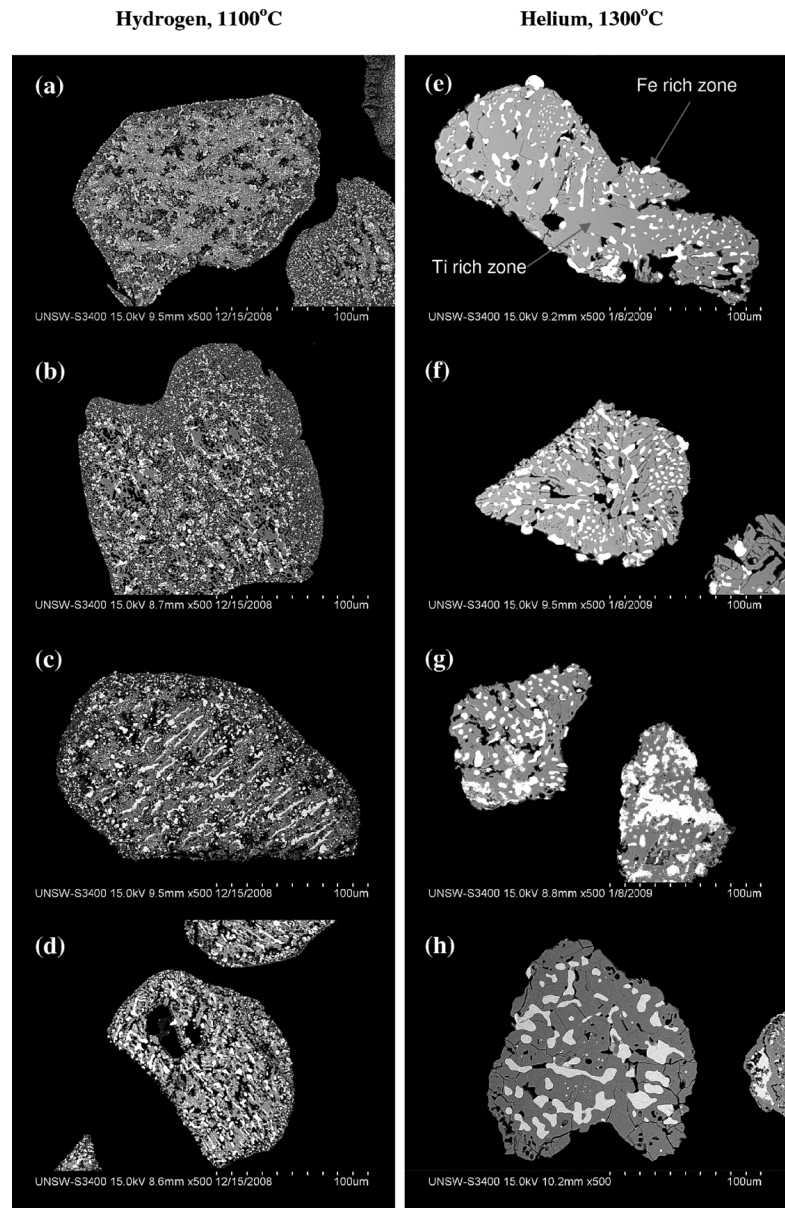

Fig. 11. SEM/BSE images of primary ilmenite at different stages of reduction in hydrogen at $1100^{\circ} \mathrm{C}$ and helium at $1300^{\circ} \mathrm{C}$; (a, e) $30 \mathrm{~min},(\mathrm{~b}, \mathrm{f}) 60 \mathrm{~min},(\mathrm{c}, \mathrm{g}) 180 \mathrm{~min},(\mathrm{~d}, \mathrm{~h})$ $300 \mathrm{~min}$.

and synthetic rutile in temperature programmed reduction and isothermal experiments in different gas atmospheres. The main conclusions are summarised as follows.

(1) Carbothermal reduction of ilmenite concentrates proceeded in two main stages. In the first stage, ilmenite concentrates were reduced to metallic iron and titania. Second stage involved the reduction of titania to titanium oxycarbide.

(2) Pseudorutile was first reduced to ilmenite and titania, followed by reduction of ilmenite to metallic iron and titania. Titania was reduced to $\mathrm{Ti}_{3} \mathrm{O}_{5}$, and then $\mathrm{Ti}_{2} \mathrm{O}_{3}$, which was converted to titanium oxycarbide.

(3) Reduction of ilmenite concentrates in hydrogen significantly changed the ilmenite structure; it produced fine grains of metallic iron and titanium suboxides, which facilitated conversion of titanium oxide to oxycarbide. The higher the iron oxide content, the faster the reduction and carburization rate.

(4) The change of particles morphology in the reduction in inert gases was not significant. The highest reduction/carburization rate in argon and helium was observed for synthetic rutile which had the highest porosity.

\section{Acknowledgements}

This research was supported under Australian Research Council's Linkage Projects funding scheme (project num- 
ber LP0455085). Professor Ostrovski is the recipient of an Australian Research Council Professorial Fellowship (project number DP0771059). Primary ilmenite concentrate was supplied by Iluka Resources Limited.

\section{REFERENCES}

1) T. Chernet: Int. J. Miner. Process., 57 (1999), 153

2) M. Dewan, G. Zhang and O. Ostrovski: Metall. Mater. Trans. B, (Published Online)

3) A. Adipuri, G. Zhang and O. Ostrovski: Metall. Mater. Trans. B, 39 (2008), 23
4) M. I. Pownceby, G. J. Sparrow and M. J. Fisher-White: Miner. Eng., 21 (2008), 587

5) M. I. Elguindy and W. G. Davenpor: Metall. Trans., 1 (1970), 1729.

6) S. K. Gupta, V. Rajakumar and P. Grieveson: Metall. Trans. B, 18 (1987), 713

7) S. K. Gupta, V. Rajakumar and P. Grieveson: Metall. Trans. B, 20 (1989), 735.

8) Y. Wang and Z. Yuan: Int. J. Miner. Process., 81 (2006), 133.

9) H. J. Wouterlood: J. Chem. Technol. Biotechnol., 29 (1979), 603.

10) M. Dewan, G. Zhang and O. Ostrovski: Metall. Mater. Trans. B, 40 (2009), 62.

11) G. Zhang and O. Ostrovski: Metall. Mater. Trans. B, 31 (2000), 129. 